C 型肝硬変に対する生体肝移植後に急速な経過をたどり死亡した fibrosing cholestatic hepatitis $の 1$ 例

九州大学大学院消化器 - 総合外科, 徳島大学器官病態修復医学講座臓器病態外科学分野*
米 村 祐 輔 島 田 光 生* 吉 住 朋 睛
武 冨 紹 信 前 原 喜 彦

ウイルス性肝硬変に対する肝移植は近年増加傾向にある，C型肝硬変に対する移植の 問題点は移植後の $\mathrm{C}$ 型肝炎の再発であり, 術後 1 年以内に $50 \sim 60 \%$ が組織学的に慢性活 動性肝炎を再発し, 術後 5 年で約 $20 \%$ が肝硬変に進行するとされている。C型肝炎の場 合, 肝炎の再発はほとんどが軽度であり，緩徐な経過が特街とされている.一方, fibrosing cholestatic hepatitis (FCH) は組織学的に胆汁うっ滞, 門脈周囲の線維化, 肝細胞 腫大, 軽度な炎症などの特徵を認め短期間で肝硬変に進行し, 主にB 型肝硬変における 移植後の肝炎再発形式とされている。近年, C 型肝硬変に対する移植後にも $\mathrm{FCH}$ が認め られ，近年增加傾向にあるとされている。今回われわれは C 型肝硬変に対する生体肝移 植術後に高ビリルビン血症を認め組織学的に急速な線維化をきたし術後233日目にグラ フト機能不全で死亡した FCH 症例を経験したので報告する。

索引用語：生体肝移植, C 型肝炎, fibrosing cholestatic hepatitis(FCH)

\section{緒言}

C 型肝炎に対する肝移植後の問題点は高率に肝炎が 再発することである.一般に, C 型肝炎の再発は軽度で 経過が緩徐であるとされている1 -3).一方, fibrosing cholestatic hepatitis (FCH) は急速に肝硬変へと進行 する病驡であり，主にB 型肝炎に対する移植後に認め られる。しかしながら稀ではあるが近年 C 型肝炎に対 する移植後の $\mathrm{FCH}$ が報告されている334. 当科では， $\mathrm{HCV}$ 陽性患者に対してこれまでに生体肝移植を51例 施行しており, 今回われわれは生体肝移植術後に, FCH を発症し急速な経過をたどった症例を経験した ので報告する。

$$
\text { 症例 }
$$

症例：40歳，男性.

主訴：全身倦急感, 腹部膨満。

既往歴, 家族歴：特記すべき事項なし。

現病歴：1997年, 腹部膨満を自覚し, 近医を受彰し た際腹水を認めた。 HCV 陽性ちよび肝硬変を指摘さ

2004年 5 月25日受付 2004 年 8 月31日採用

〈所属施設住所〉

T812-8582 福岡市東区馬出 $3-1-1$
れ，上部消化管内視鏡にて食道静眽溜を認め内視鏡下 静脈痹結愁術を施行された，その後，利尿剤の内服に て経過観察されていた。 2001年 8 月, 再び腹部膨满感 が出現. 近医入院の上, 腹水コントロールを行い 3 週 間で退院した。2002年10月，腹水コントロール目的で 再入院. 精査にて著明な肝機能の低下を認めた。11月 に感冒を契機に肝機能が悪化し，生体肝移植目的で当 院を紹介され，12月10日，適応評価目的にて当科入院 となった。

入院時現症：黄㾝・腹水著明, 脾腫あり, 肝性脑症 I 度.

入院時検査所見 : 血 液 型 $\mathrm{AB}$ 型 $\mathrm{Rh}(+)$, 〈血 算〉 WBC $17,380 / \mathrm{mm}^{3}, \mathrm{RBC} 292 / \mathrm{mm}^{3}, \mathrm{Hb} 10.3 \mathrm{~g} / \mathrm{dl}, \mathrm{Ht}$ $29.0 \%$, Plt 13.3 万 $/ \mathrm{mm}^{3}$, 〈生化学〉TP $6.1 \mathrm{~g} / \mathrm{dl}, \mathrm{Alb}$ $3.2 \mathrm{~g} / \mathrm{dl}, \mathrm{BUN} 51 \mathrm{mg} / \mathrm{dl}, \mathrm{Cr} 1.81 \mathrm{mg} / \mathrm{dl}$, Ccr $29.0 \mathrm{ml} /$ $\mathrm{min}, \mathrm{TB} 11.1 \mathrm{mg} / \mathrm{dl}$, DB $8.1 \mathrm{mg} / \mathrm{dl}$, TTT $6.8 \mathrm{KU}$, ZTT 13.0KU, AST 94IU/1, ALT 49IU/1, LDH 242 $\mathrm{IU} / \mathrm{l}, \mathrm{ChE} 15 \mathrm{IU} / \mathrm{l}, \mathrm{Na} 125 \mathrm{mEq} / \mathrm{l}, \mathrm{K} 5.1 \mathrm{mEq} / \mathrm{l}, \mathrm{Cl} 95$ $\mathrm{mEq} / \mathrm{l}$. T-chol 43mg/dl, TBA $241.5 \mu \mathrm{mol} / 1, \mathrm{NH}_{3} 42$ $\mu \mathrm{g} / \mathrm{dl}$. 〈凝固系〉 PT 16.8 (11.2) sec, PT \% 46\%, HPT 35\%. 〈ウイルスマーカー〉IgM-HA(-), $\operatorname{HBsAg}(-), \operatorname{HBsAb}(-), \operatorname{HBeAg}(-), \operatorname{HBeAb}(-)$, 


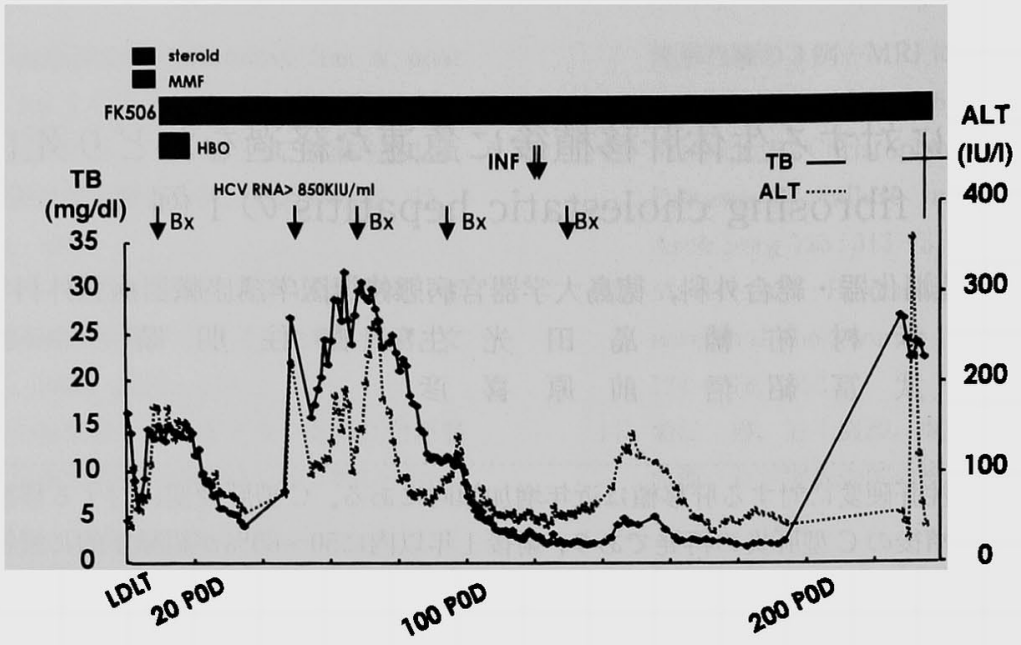

図 1 肝移植後の経過(MMF : ミコフェノール酸モフェティル, HBO : 高圧酸素 療法, INF：インターフェロン, Bx：肝生検, $\mathrm{TB}$ ：総ビリルビン, LDLT：生 体肝移植, POD : 術後日数)

$\mathrm{HBcAb}(-)$, HBV DNA(-), HCV Ab(+), AMA $(-)$, ANA (-).〈腫崵マーカー AFP 6.2ng/ml, PIVKA $17 \mathrm{mAU} / \mathrm{ml}$.

入院時画像所見：肝萎縮, 著明な脾腫, 大量の腹水 あり.腫瘍性病変やシャントは認めず.

手術：2003年 1 月 7 日, 39歳の実弟( A 型 $\mathrm{Rh}+$, 適 合）をドナーとして生体肝移植術を施行. 拡大左葉 + 尾状葉グラフト,グラフト重量 $370 \mathrm{~g}, \mathrm{GV} / \mathrm{SLV}=33.6$ $\%, \mathrm{GRWR}=0.73 \%$, 手術時間：12時間11分, 出血量： $11,486 \mathrm{~g}$.

術後経過：免疫抑制剤は, ステロイド,ミコフェノ ール酸モフェチル,バシリキシマブの 3 片で導入. $\mathrm{HCV}$ 陽性のためステロイドは 1 週間で中止し, 以後 FK 506の投与のみとした (図 1). 術後 7 日目よりビリ ルビン, トランスアミナーゼの上昇を認め臨床的に small-for-size graft syndrome と診断し, 高圧酸素療 法を開始した。ビリルビン $(2 \sim 3 \mathrm{mg} / \mathrm{dl})$, トランス アミナーゼが正常化し術後34日目に退院となった。術 後 52 日目より再度ビリルビン $(15.9 \mathrm{mg} / \mathrm{dl})$, トランス アミナーゼの再上昇を認めた。術後55日目の HCV RNA は検出限界の上限を超えており（HCV RNA> $850 \mathrm{KIU} / \mathrm{ml}), \mathrm{C}$ 型肝炎の再発が疑われた。術後76日目 の肝生検（術後 3 回目）にて, 門脈域周囲の偽胆管の 増生と, 軽度の炎症細胞浸潤, 中心静脈周囲の胆汁う つ滞とうっ血および軽度の肝細胞の腫大を認め, 軽度 の肝炎の診断にて肝庇護剤の投与を施行 (図 2 ). その 後, ビリルピン, トランスアミナーゼは低下したが再
上昇を認めたため術後 97 日目に肝生検（術後 4 回目） を施行した。門脈域周囲の偽胆管増生, 炎症細胞浸潤, 中心静脈周囲の肝細胞の腫大, 脂肪化，好酸性小体を 認め, C 型肝炎の再発に伴う肝炎の所見であった (図 3).その後トランスアミナーゼは軽度上昇程度まで下 がったが, 白血球減少のため INF+リバビリン療法が 施行できず低容量 IFN 療法 (300万 IU× 1 /day) を施 行した. しかし, 白血球減少が進行し, 2 回施行後に 中止した。術後135日目 ( 5 回目) の肝生検では, 門脈 域周囲の偽胆管増生と炎症細胞浸潤を認め, マッソ ン・トリクローム染色では架橋線維化を認めた(図 4). その後, 腹水の増加を認め肝不全となり術後233日目に 死亡した. 死亡時の肝組織は広範性壊死を伴った肝硬 変の所見であった（図 5 ).

$$
\text { 考 察 }
$$

$\mathrm{C}$ 型肝硬変症例に対する肝移植の問題点は, 移植後 の肝炎の再発である. 術後 1 年以内に $50 \sim 60 \%$ が組織 学的に慢性活動性肝炎を呈し, 術後 5 年で約 $20 \%$ が肝 硬変に進行することが知られている. 長期的には肝炎 再発はほ济全例に起こると考えられている(1)31. 一方, 本症例のように, 移植後急速に肝硬変へと進行する $\mathrm{FCH}$ は本来肝移植後の B 型肝炎の再発形式と考えら れ, 急速に肝硬変へと進行し肝不全に至る肝炎として

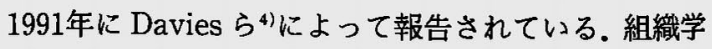
的には胆汁うっ滞と門脈域周囲から小葉内へと進展す る線維化と胆汁うっ滞を特徵とする肝炎であるが, 炎 症細胞浸潤は比較的軽度とされている4). 血清学的に 

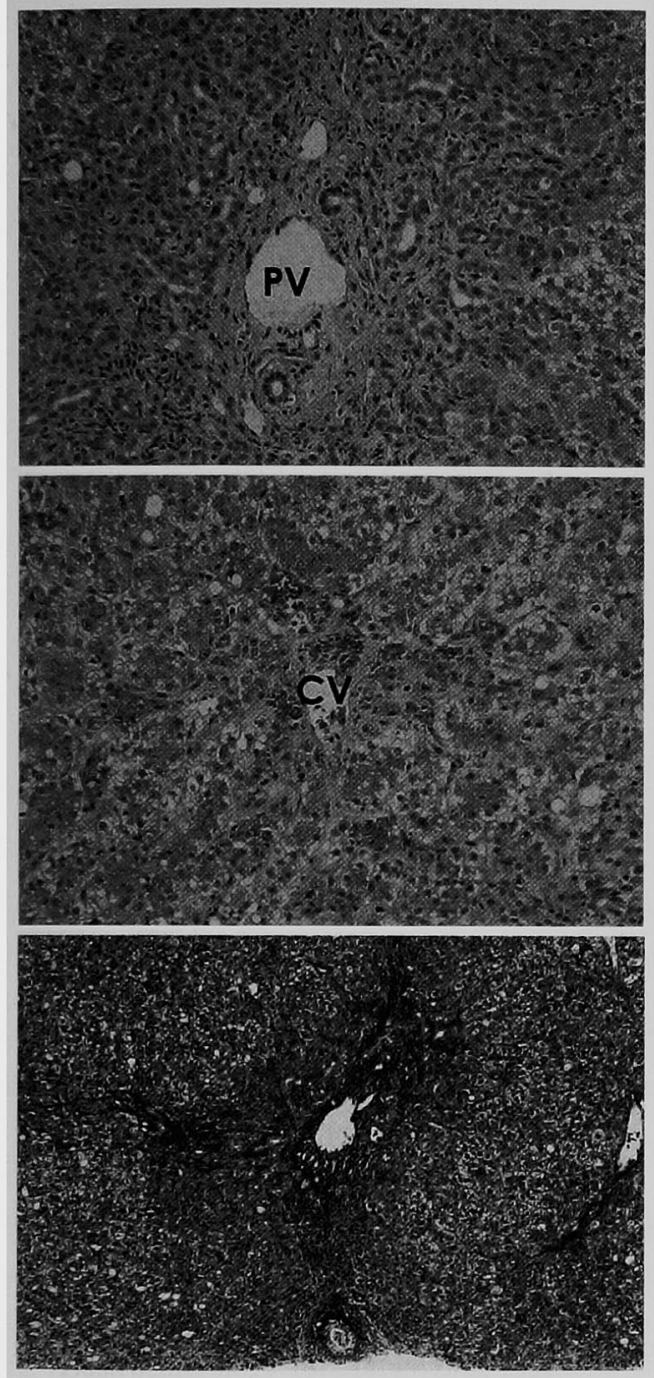

図 2 肝生検病理組織標本(術後76日目)：a)門脈域 辺縁部での偽胆管増生, 炎症細胞浸潤は軽度 (H-E 染色, $\times 100)$. b) 中心静脈周囲での胆汁うっ滞，う っ血, 軽度の肝細胞の腫大 $(\mathrm{H}-\mathrm{E}$ 染色, $\times 100)$. c ) 門脈域加ら葉内へ進展する網目状の線維化

(Masson's trichrome 染色, $\times 40$ ). $\frac{a}{b}$

は肝機能低下に伴うプロトロンビン時間の延長，アル カリフォスファターゼの上昇, 比較的低い值の ALT である ${ }^{5)}$. 臨床的特徵は免疫抑制状態, つまり臓器移植 後での免疫抑制剤投与下や, HIV 陽性患者において発 症しやすく，急速に肝の線維化が進行し肝硬変に至り 肝不全に宿ることである ${ }^{6) \sim 9)}$. FCH は HBV 陽性患者
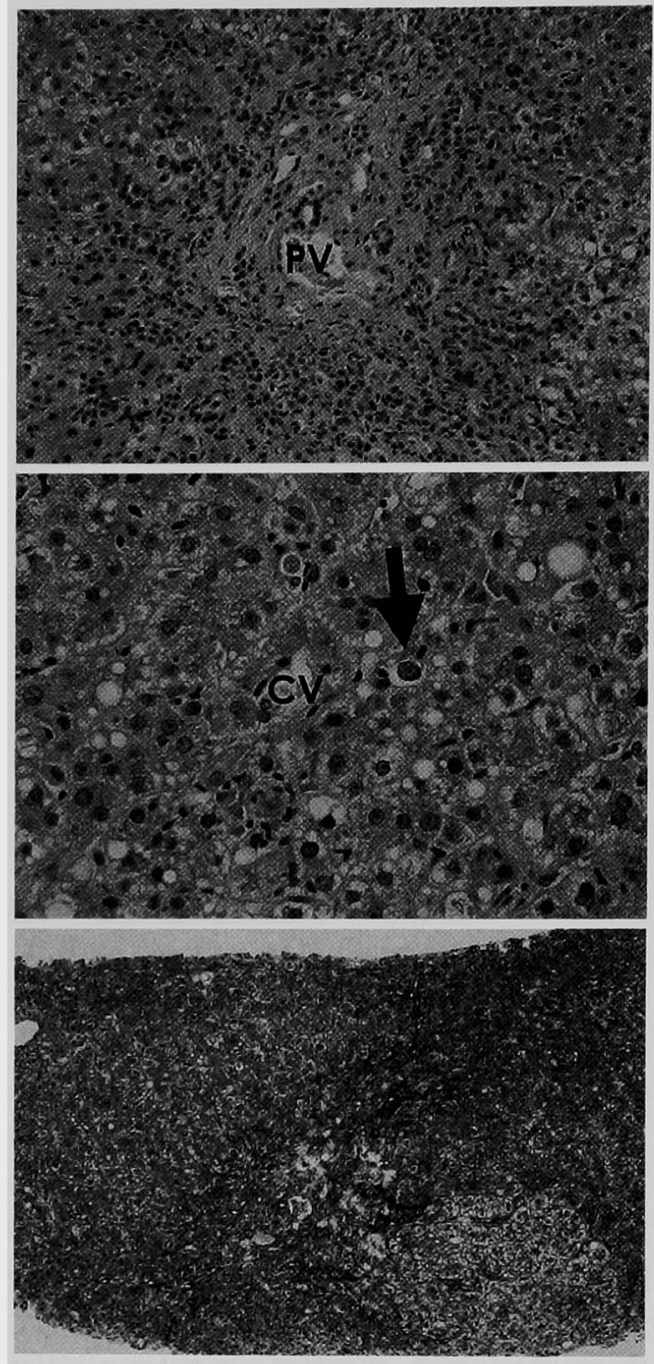

図 3 肝生検病理組織標本(術後97日目)：a)門脈域 周囲での偽胆管増生, 炎症細胞浸潤は強い $(\mathrm{H}-\mathrm{E}$ 染 色, $\times 100) . b)$ 中心静脈周囲での肝細胞の腫大, 脂 肪化, 好酸性小体 $(\mathrm{H}-\mathrm{E}$ 染色, $\times 100)$. c) 門脈域 から小葉内へ進展する線維化の増強 (Masson's trichrome 染色, $\times 40$ ).

$\frac{a}{b}$

における肝移植後の肝炎再発時の特徴とされてきた が, 最近 FCH が臓器移植後の HCV の再発の際に認 められ注目されている(1011). 特に $\mathrm{HCV}$ 陽性患者の FCH は, 腎もしくは肝移植後の 1 〜 \%に認められそ の頻度は最近增加傾向にあるといわれているる12). $\mathrm{HCV}$ における FCH 発症にも免疫不全状態が関与し 

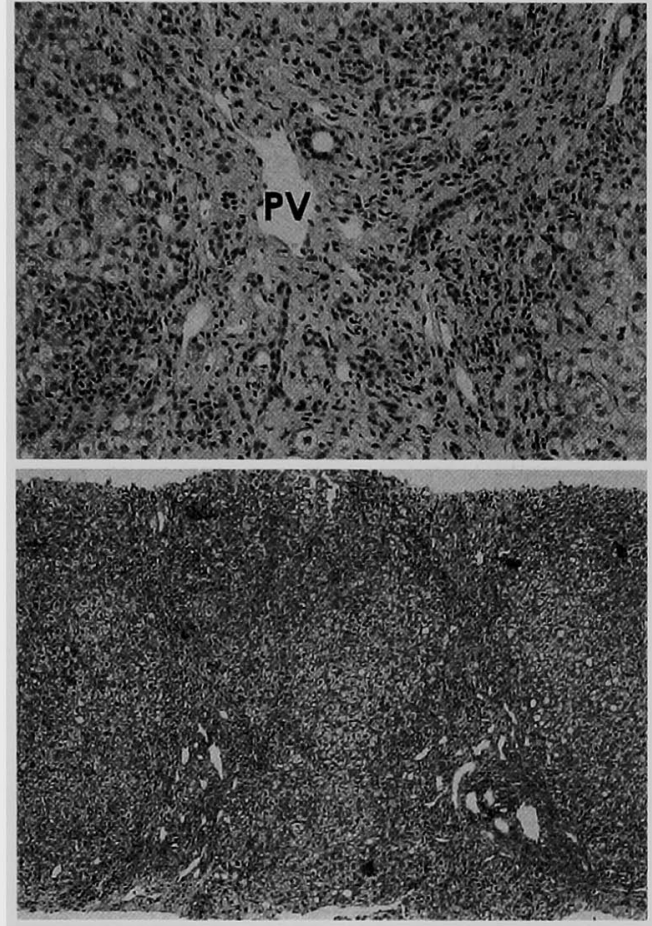

図 4 肝生検病理組織標本 (術後135日目)：a）門脈 域周囲での偽胆管増生, 炎症像 (H-E 染色, $\times 100)$. b) 架橋線維化 (Masson's trichrome 染色, $\times 40$ ).

ており, HBV と同様に臟器移植後, HIV 陽性患者に も認められ, 拒絶の治療をはじめ, CMV 感染や胆汁箁 帯がリスクファクターである ${ }^{13)}$. FCH の治療として再 移植が挙げられるが，再移植後も再発することも多く ドナーの有無の問題があり実際には行われないのが現 状である ${ }^{14}$. したがって, 早期発見が重要であり, 肝機 能が低下する前に IFN+リバビリン療法を施行する ことでグラフト不全を回避できる可能性がある ${ }^{15)}$. 今 回, われわれが経験した症例では, HCV RNA 検査で は術後早期（術後55日目）に高值となり, 組織学的に も術後76日目の肝生検で既に, FCH を示唆する所見を 認めた。しかし，肝機能不良のため IFN+リバビリン 療法が施行できず, 低容量 IFN 療法を試みるも開始 3 日目で好中球減少をきたし治療継続困難であった，C 型肝硬変に対する肝移植術後は肝炎の再発は必発であ り,FCH のように急速にグラフト不全をきたす症例も あるため，早期診断には定期的な肝生検と予防的な IFN+リバビリン療法の施行が安全かつ効果的に行え
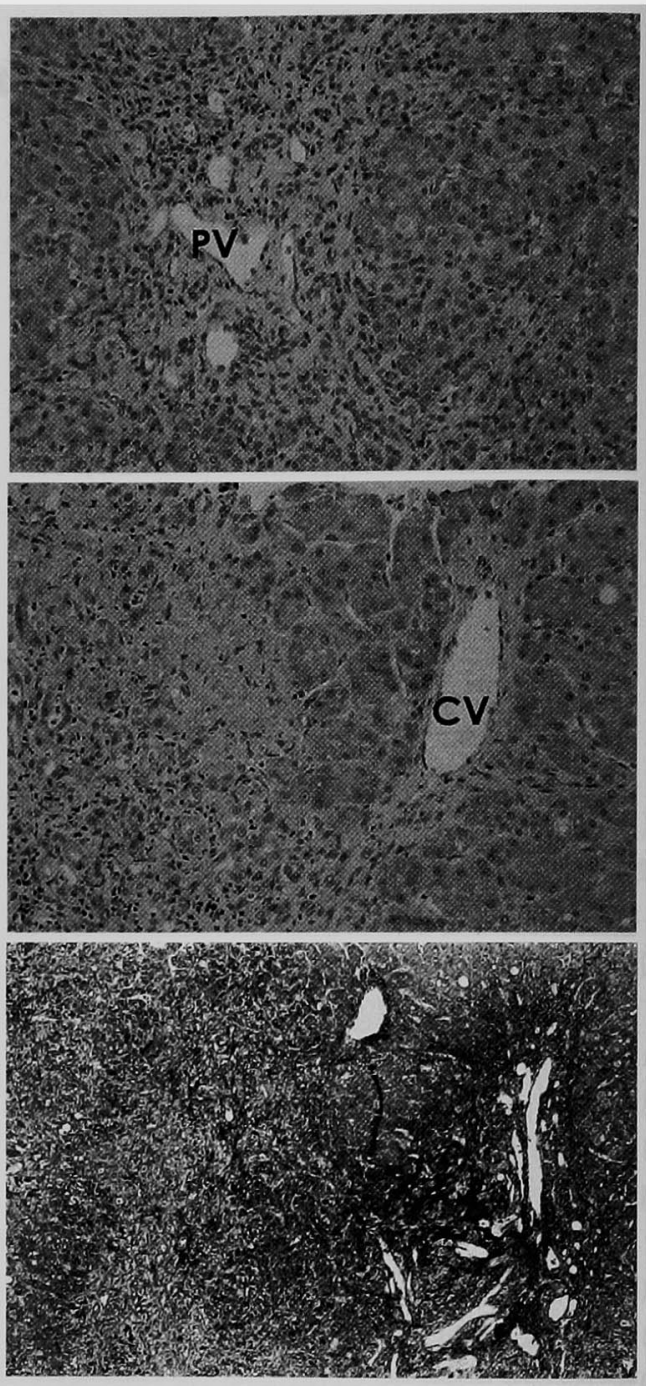

图 5 死亡時肝病理組織標本 (術後233日目)：a）門 脈域周囲での偽胆管增生, 軽度〜中等度のリンパ球 を主体とした炎症細胞浸潤 (H-E 染色, $\times 100)$. b) 広管性肝壊死, 高度の線維化 $(\mathrm{H}-\mathrm{E}$ 染色, $\times 100)$. c) 小葉構築を破壞する高度の線維化 (Masson's trichrome 染色, $\times 40$ ).

$$
\frac{\mathrm{a}}{\mathrm{b}}
$$

るプロトコールの作成が今後の課題である. 肝炎再発 の予防や再発後の効果的な治療法が切望される.

\section{結 語}

$\mathrm{HCV}$ 陽性患者における生体肝移植術後に FCH を 認めた場合，早期にグラフト不全をきたす可能性があ ることに十分留意すべきである。したがって，FCHに 
対し, 肝機能が低下する前に IFN+リバビリン療法を 行えるように肝移植後に高ビリルビン血症を認めた場 合，肝生検を行い早期埥断に努めるべきである.

\section{References}

1) Feray C, Gigou M, Samuel D, et al: The course of hepatitis $C$ virus infection after liver transplantation. Hepatology 20:1137-1143, 1994

2) Gane EJ, Bernard C, Portman BC, et al : Longterm outcome of hepatitis $C$ infection after liver transplantation. N Eng J Med $334: 815-$ 820,1996

3) Alberto SF, Juan CR, Llorenc $Q$, et al : Impact of the recurrence of hepatitis $C$ virus infection after liver transplantation on the long-term viability of the graft. Transplantation $73: 56-$ 63, 2002

4) Davies SE, Portmann BC, O'Grady JG, et al: Hepatic histological findings after transplantation for chronic hepatitis B virus infection, including a unique pattern of fibrosing cholestatic hepatitis. Hepatology $13: 150-157,1991$

5) Jonathan CLB, Rob DG, Jonathan LB, et al: Fibrosing cholestatic hepatitis in a renal transplant recipient associated with the hepatitis $B$ virus precore mutant. J Hepatol $22: 500-503$, 1995

6) Chen $\mathrm{CH}$, Chen PJ, Chu JS, et al: Fibrosing cholestatic hepatitis in a hepatitis $B$ surface antigen carrier after renal transplantation. Gastroenterology $107: 1514-1518,1994$

7) Cooksley WG, Mclvor CA : Fibrosing cholestatic hepatitis and HBV after bone marrow transplantation. Biomed Pharmacother $49: 117$ $-124,1995$
8) Fang JWS, Wright TL, Lau JYN : Fibrosing cholestatic hepatitis in patient with HIV and hepatitis B. Lancet $342: 1175,1993$

9) Rosenberg PM, Farrell JJ, Abraczinskas DR, et al: Rapidly progressive fibrosing cholestatic hepatitis $\mathrm{C}$ virus in HIV coinfection. Am J Gastroenterol $9: 478-483,2002$

10) Lim HL, Lau GKK, Davis GL, et al: Cholestatic hepatitis leading to hepatic failure in a patient with organ-transmitted hepatitis $\mathrm{C}$ virus infection. Gastroenterology $106: 248-$ 251, 1994

11) Schluger $L$, Sheiner $P$, Thung $S$, et al : Severe recurrent cholestatic hepatitis $C$ following orthotopic liver transplantation. Hepatology 23: $971-976,1996$

12) Delladetsima JK, Boletis JN, Makris F, et al: Fibrosing cholestatic hepatitis in renal transplant recipients with hepatitis $C$ virus infection. Liver Transpl Surg $5: 294-300,1999$

13) Toth CM, Pascual M, Chung RT, et al : Hepatitis C virus-associated fibrosing cholestatic hepatitis after renal transplantation: response to interferon-alpha therapy. Transplantation $66: 1254-1258,1998$

14) Berenguer M, Ferrell $L$, Watson J, et al : HCV -related fibrosis progression following liver transplantation: increase in recent years. J Hepatol $32: 673-684,2000$

15) Mazzaferro V, Tagger A, Schiavo $M$, et al: Prevention of recurrent hepatitis $C$ after liver transplantation with early interferon and ribavirin treatment. Transplant Proc $33: 1355$ $-1357,2001$ 


\title{
RAPIDLY PROGRESSED FIBROSING CHOLESTATIC HEPATITIS AFTER LIVING DONOR LIVER TRANSPLANTATION FOR HCV-RELATED CIRRHOSIS-REPORT OF A CASE-
}

\author{
Yusuke YONEMURA, Mitsuo SHIMADA*, Tomoharu YOSHIZUMI, \\ Akinobu TAKETOMI and Yoshihiko MAEHARA \\ Department of Surgery and Science, Graduate School of Medical Sciences, Kyushu University \\ *Course of Diseased Organ and Repair Medicine, Department of Digestive and Pediatric Surgery, \\ The University of Tokushima School of Medicine
}

Liver transplantation (LTx) for liver cirrhosis caused by hepatitis $C$ virus is increasing in recent years. The problem of LTx for cirrhosis due to hepatitis $C$ is the reactivation of hepatitis $C$ virus after transplantation. Approximately $50-60 \%$ of patients will develop chronic active hepatitis within one year after transplantation. In addition, $20 \%$ of those patients develop liver cirrhosis within five years. Unlike hepatitis $\mathrm{B}$, recurrent hepatitis $\mathrm{C}$ is usually mild and is characterized by gradual progress. On the other hand, fibrosing cholestatic hepatitis $(\mathrm{FCH})$, a specific histologic manifestation of hepatitis $\mathrm{B}$ virus infection, is characterized by periportal fibrosis, hepatocyte ballooning, cholestasis and relatively scant inflammation. FCH will rapidly progress to liver cirrhosis for a short period of time. In recent years, $\mathrm{FCH}$ has been increasingly reported to occur after $\mathrm{LTx}$ for hepatitis $\mathrm{C}$ cirrhosis. Herein, we report a case of FCH after living-donor LTx for hepatitis C, which led to a rapid graft loss on POD 233. 